\title{
EFEKTIVITAS LAYANAN KONSELING KELOMPOK TEKNIK RESTRUKTURISASI KOGNITIF UNTUK MEREDUKSI KECEMASAN MENGHADAPI UJIAN SISWA KELAS VII SMP N 22 KOTA BENGKULU
}

\author{
Anggia Maretta Ireel, Yessy Elita, Arsyadani Mishbahuddin \\ Prodi Bimbingan dan Konseling Fakultas Keguruan dan Ilmu Pendidikan \\ Universitas Bengkulu \\ Anggiamaretta95@gmail.com, yessyelita@unib.ac.id,arsyadani@unib.ac.id
}

\begin{abstract}
ABSTRAK
Penelitian ini bertujuan untuk mendeskripsikan efektivitas layanan konseling kelompok melalui teknik restrukturisasi kognitif dalam mereduksi kecemasan siswa menghadapi ujian di SMP Negeri 22 Kota Bengkulu. Penelitian ini adalah eksperiment pre-test dan post-test one group design. Sampel dalam penelitian ini adalah 10 orang siswa dari kelas VII C yang memiliki tingkat kecemasan menghadapi ujian tinggi dan sangat tinggi. Teknik pengumpulan data dalam penelitian ini menggunakan angket. Hasil yang diperoleh dalam penelitian ini menunjukan kecemasan siswa menghadapi ujian menurun setelah diberikan layanan konseling kelompok dengan teknik restrukturisasi kognitif, hal ini terlihat dari hasil pre-test dan post-test $\mathrm{p}=0.005$ maka $\mathrm{p}<0.05$, sehingga dapat disimpulkan Ho ditolak dan $\mathrm{Ha}$ diterima, artinya terdapat pengaruh yang signifikan kecemasan siswa menghadapi ujian sebelum dan sesudah diberikan layanan konseling kelompok dengan teknik instruksi diri.
\end{abstract}

Kata kunci: kecemasan menghadapi ujian, layanan konseling kelompok, restrukturisasi kognitif.

\section{EFFECTIVENESS OF GROUP COUNSELING SERVICES THROUGH COGNITIVE RESTRUCTURING TECHNIQUES IN REDUCING THE ANXIETYSTUDENTS WITH TEST IN CLASS VII SMP NEGERI 22 KOTA BENGKULU}

\begin{abstract}
This study aims to describe the effectiveness of group counseling services through cognitive restructuring techniques in reducing the anxiety of students facing exams at SMP Negeri 22 Kota Bengkulu. This research is experiment pre-test and post-test one group design. The sample in this study were 10 students from grade VII C who have high anxiety level and high exam. Data collection techniques in this study using a questionnaire. The results obtained in this study showed the anxiety of students facing the declining test after given group counseling services with cognitive restructuring techniques, it is seen from the results of pretest and post-test $\mathrm{p}=0.005$ then $\mathrm{p}<0.05$, so it can be concluded Ho rejected and Ha accepted, Meaning that there is a significant influence of students' anxiety facing exams before and after being given counseling services group with self instruction techniques.
\end{abstract}

Keywords: anxiety facing exams, group counseling services, cognitive restructuring. 


\section{Pendahuluan}

Pendidikan merupakan faktor utama dalam membangun sumber daya manusia yang berkualitas. Pendidikan adalah aspek yang menentukan masa depan yang lebih baik bagi siswa. Pendidikan adalah aspek yang menentukan masa depan yang lebih baik bagi siswa. Pada dasarnya pendidikan bertujuan untuk mengembangkan berbagai potensi yang ada pada diri siswa agar siswa menjadi kreatif, berilmu, mandiri, cakap, berakhlak mulia, serta mempunyai keterampilan.

Hal ini sesuai dengan tujuan pendidikan nasional menurut Undangundang No. 20 tahun 2003 pasal 1 ayat (1) tentang Sistem Pendidikan Nasional menyatakan : Pendidikan adalah usaha sadar dan terencana untuk mewujudkan suasana belajar dan proses belajar agar peserta didik secara aktif mengembangkan potensi dirinya untuk memiliki kekuatan spiritual keagamaan, pengendalian diri, kecerdasan, akhlak mulia, serta keterampilan yang diperlukan dirinya, masyarakat dan negara.

Berdasarkan undang-undang tersebut dapat dipahami tujuan pendidikan nasional merupakan kondisi ideal yang senantiasa diupayakan melalui proses pendidikan terutama di sekolah. Sekolah sebagai lembaga pendidikan formal untuk tempat berlangsungnya proses belajar yang dimulai dari sekolah dasar hingga tingkat atas yang berupaya untuk mengembangkan potensi siswa. Belajar menunjukkan adanya perubahan yang sifatnya positif yaitu pada tahap akhir akan didapat keterampilan, kecakapan dan pengetahuan baru. Proses belajar disesuaikan dengan kebutuhan. Menurut Slameto (2010: 2) belajar adalah suatu proses usaha yang dilakukan seseorang untuk memperoleh suatu perubahan tingkah laku yang baru secara keseluruhan, sebagai hasil pengalaman sendiri dalam interaksi dengan lingkungannya.

Bagi siswa dengan kemiskinan ilmu pengetahuan sangat sulit untuk beradaptasi dan memahami perputaran roda zaman. Tidak seharusnya siswa terhindar dari tipu daya kemunafikan dan terjebak pada zaman iptek yang serba pesat. Akibat dari beratnya beban yang dipikul peserta didik terutama menghadapi masa-masa menentukan seperti ujian (tes) seringkali mengalami gangguan kejiwaan meskipun dalam kategori ringan. Pada umumnya orang pernah mengalami kecemasan, walaupun sering tidak dirasakan karena kecemasan ini berkisar dari sedikit rasa gelisah tidak menyadari kalau berkelanjutan hal ini merupakan stres yang menjadi parah. 
Situasi yang menekan, khususnya situasi ujian, cenderung menimbulkan kecemasan pada diri siswa. Rasa cemas besar pengaruhnya pada tingkah laku siswa. Menurut Prasetyono (2005: 11) kecemasan (anxiety) adalah penjelmaan dari berbagai proses emosi yang bercampur baur, yang terjadi manakala seseorang sedang mengalami berbagai tekanan-tekanan atau ketegangan (stress) seperti perasaan frustasi dan pertentangan batin (konflik batin). Menurut Chaplin (dalam Kartini Kartono, 2002: 32) anxiety (kecemasan atau kegelisahan) adalah perasaan campuran berisikan ketakutan dan keprihatinan mengenai masa-masa mendatang dan tanpa sebab khusus untuk ketakutan tersebut.

Kecemasan mengakibatkan siswa tidak konsentrasi sehingga berdampak mengganggu hasil belajar. Seperti yang dikemukakan oleh Kirkland (dalam Slameto, 2003 : 186) yang membuat suatu kesimpulan mengenai hubungan antara ujian, kecemasan dan hasil belajar : (a) Tingkat kecemasan yang sedang biasanya mendorong belajar, sedangkan tingkat kecemasan yang tinggi mengganggu belajar. (b) Siswa-siswa dengan tingkat kepandaian yang rendah merasa cemas dalam menghadapi ujian daripada siswasiswa yang pandai. (c) Bila siswa cukup mengenal jenis tes/ujian yang dihadapi, maka kecemasan akan berkurang. (d) Pada tes/ujian yang mengukur daya ingat, siswasiswa yang sangat cemas memberikan hasil yang lebih baik daripada siswa-siswa yang kurang cemas. (e) Pada tes/ujian yang membutuhkan cara berpikir yang fleksibel, siswa-siswa yang sangat cemas hasilnya lebih buruk. (f) Kecemasan terhadap tes/ujian bertambah bila hasil tes/ujian dipakai untuk menetukan tingkat-tingkat siswa.

Permasalahan yang terjadi di SMP N 22 Kota Bengkulu dapat diketahui bahwa masih banyak siswa yang memiliki tingkat kecemasan tinggi pada saat menghadapi ujian, khususnya kelas VII yang umumnya berusia 14-15 tahun. Pada usia tersebut dapat dikatakan masuk pada usia remaja yang perkembangan kognitifnya mengalami peralihan dari masa anak-anak. Siswa yang mengalami kecemasan saat menghadapi ujian/tes pada umumnya menunjukkan tanda seperti gugup, tegang, berkeringat dingin, badan gemetar, gelisah, sulit konsentrasi, dan mereka cenderung menghindari untuk mengerjakannya.

Hal ini timbul karena pikiran-pikiran negatif siswa dan disertai dengan adanya sedikit gejala-gejala dalam masalah kesehatan dan fisik seperti perubahan pola tidur, tegang, kelelahan fisik dan sulit berkonsentrasi. Oleh karena itu, siswa 
cenderung menarik diri apabila menghadapi ujian, kegiatan ujian atau tes tersebut yang dapat menghasilkan nilai buruk pada mata pelajaran tertentu dan berpengaruh terhadap prestasi akademiknya.

Salah satu solusi yang dilakukan dalam mengatasi tingginya kecemasan siswa menghadapi ujian adalah dengan cara memberikan pelayanan konseling kelompok dengan teknik restrukturisasi kognitif, karena dapat memanfaatkan dinamika kelompok sebagai pengetahuan dan latihanlatihan kognitif untuk mengembalikan pemikiran yang positif, objektif dan rasional rangka dapat menurunkan kecemasan siswa menghadapi ujian.

Pemikiran atau fantasi merupakan salah satu faktor interen yang termasuk dalam faktor psikologi yang mempengaruhi proses belajar. Kecemasan terjadi karena membayangkan atau bertindak seakan-akan bahaya itu nyata, padahal kenyataannya tidak terjadi atau belum terjadi. Mempersepsikan negatif tentang sesuatu, diri anda sendiri ataupun lingkungan di luar diri anda. Tidak menutup kemungkinan adanya pemikiran irasional yang terjadi pada siswa yang mengalami kecemasan dalam menghadapi ujian/tes dan ketakutan untuk gagal pada saat mengerjakan soal. Ketika pemikiran irasional hadir dalam cara berpikir siswa, maka juga akan berpengaruh terhadap prestasi belajar siswa.

Tingkatan kecemasan individu tergantung pada situasi, beratnya impuls yang datang dan kemampuan untuk mengendalikan diri dalam menghadapi persoalan. Proses terbentuknya kecemasan ujian dapat digambarkan dengan urutan. Adanya stimulus berupa bayangan ancaman atau bahaya potensial yang muncul saat menghadapi ujian, kemudian memicu kecemasan dan menyebabkan siswa terseret dalam pikiran yang mencemaskan. Sebab awal dari kecemasan itu adalah tanggapan pikiran dalam mempersepsikan stimulus yang diterima oleh siswa saat ujian.

Konseling kelompok menurut Mashudi (2012: 248) adalah layanan yang membantu peserta didik dalam pembahasan dan pengentasan masalah pribadi melalui dinamika kelompok. Sedangkan menurut Prayitno (2012: 149), bahwa konseling kelompok adalah mengaktifkan dinamika kelompok untuk membahas berbagai hal yang berguna bagi pengembangan pribadi dan/atau pemecahan masalah individu yang menjadi peserta kegiatan kelompok.

Kegiatan dalam konseling kelompok ini memberikan informasi dan kegiata untuk keperluan bersama para anggota kelompok, yang diantaranya cara yang mudah saling mengenal dan membantu 
dengan cara yang sistemastis untuk memecahkan masalah anggota kelompok (Nurihsan, 2011: 24). Dengan melalui layanan konseling kelompok ini penulis mencoba memberikan pengarahan dengan teknik restrukturisasi kognitif, diharapkan siswa dapat menurunkan kecemasan dalam menghadapi ujian.

Menurut Cormier \& Nurius (dalam Krisnayana dkk, 2014: 6) bahwa restrukturisasi kognitif berakar pada pengapusan distorsi kognitif atau kesimpulan yang salah, pikiran, keyakinan irasional, dan mengembangkan kognisi baru dengan pola respon yang lebih baik atau sehat. Menurut Dombeck (dalam Bradley, 2016: 255) Cognitive restructuring melibatkan penerapan prinsip-prinsip belajar pada pikiran. Teknik ini dirancang untuk membantu mencapai respons emosional yang lebih baik dengan mengubah kebiasaan penilaian habitual sedemikian rupa

Menurut Connolly (dalam Sholihat, 2012: 55) restrukturisasi kognitif membantu konseli untuk belajar berpikir secara berbeda, untuk mengubah pemikiran yang salah, mendasar dan menggantinya dengan pemikiran yang lebih rasional, realistis, dan positif. Kesalahan berpikir diekspresikan melalui pernyataan diri yang negatif. Pernyataan diri yang negatif mengindikasikan adanya pikiran, pandangan dan keyakinan yang irasional.

Untuk mengatasi kecemasan saat menghadapi ujian dapat digunakan teknik pengubahan pola pikir, agar siswa dapat mengubah pikiran-pikiran negatif menjadi pikiran-pikiran positif, serta membantu klien mengubah pandangan negatif pada kegagalan dan membuat klien lebih bersedia untuk melaksanakan kegiatan yang diinginkan yaitu dengan konseling kelompok menggunakan teknik rekstrukturisasi kognitif.

\section{Metode Penelitian}

Desain yang digunakan dalam penelitian adalah pre eksperimental design, yang dilakukan dengan memberikan perlakuan (treatment) tertentu dengan subjek penelitian (one group pretestposttest design). Jadi subjek dikenakan dua kali pengukuran. Dengan demikian perlakuan dapat diketahui lebih akurat, karena membandingkian hasil yang diperoleh sesudah perlakuan dengan keadaan sebelum diberi perlakuan. Perbedaan antara pre-test dan post-test diasumsikan sebagai efek dari treatment atau eksperimen. Desain tersebut digambarkan sebagai berikut:

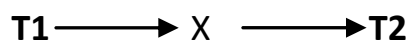


Keterangan :

T1 : Pre-test (tes sebelum konseling kelompok)

$\mathrm{X}$ : Treatment (pemberian konseling kelompok)

T2 : Post-test (tes sesudah konseling kelompok)

Populasi merupakan keseluruhan objek atau subjek yang berada pada suatu wilayah dan memenuhi syarat tertentu berkaitan dengan masalah penelitian. Populasi juga dapat didefinisikan sebagai keseluruhan unit atau individu dalam ruang lingkup yang akan diteliti (Martono, 2014: 76). Populasi dalam penelitian ini adalah siswa kelas VII SMP N 22 Kota Bengkulu.

Sampel adalah sebagian anggota populasi yang memberikan keterangan atau data yang diperlukan dalam suatu penelitian (Toha, 2008) sampel yang digunakan dalam penelitian ini berjumlah 10 siswa dengan kriteria siswa yang tingkat kecemasan menghadapi ujian tinggi. Teknik pengumpulan data menggunakan angket dan teknik analisis data menggunakan uji validitas, uji reabilitas dan uji hipotesis.

Suatu instrumen dikatakan valid jika instrumen yang digunakan dapat mengukur Tabel 1. Pre-test apa yang hendak diukur. Penelitian ini menggunakan validitas isi, yaitu mengukur sejauhmana alat isi pengukur tersebut mewakili seluruh aspek yang dianggap sebagai kerangka konsep yang akan diukur. Angket kecemasan menghadapi ujian ini melibatkan para ahli.

Keandalan (reliabel) suatu angket menujukkan ketetapan atau ketelitian suatu alat evaluasi. Pada saat melakukan uji reliabilitas, peneliti menggunakan software statistical packages for social scince (SPSS) versi 16.0. Jika $\mathrm{r}$ dihitung $>\mathrm{t}$ tabel yaitu 0,800 maka instumen dapat dikatakan reliabel. Pada penelitian ini menunjukkan cronbach's alpha sebesar 0,902 yang berarti instumen tersebut memiliki reliabilitas.

\section{Hasil dan Pembahasan}

Analisis hasil penelitia dari pre-test dan post-test kecemasan menghadapi ujian pada siswa kelas VII C SMP N 22 Kota Bengkulu.

\begin{tabular}{ccc}
\hline Interval & Frekuensi & Kategori \\
\hline$>107$ & 4 & Sangat tinggi \\
\hline
\end{tabular}




\begin{tabular}{ccc}
\hline $97-106$ & 4 & Tinggi \\
\hline $86-96$ & 2 & Sedang \\
\hline $65-85$ & 8 & Rendah \\
\hline$<64$ & 1 & Sangat rendah \\
\hline Total & 19 & \\
\hline
\end{tabular}

Berdasarkan hasil pengambilan data awal (pre-test) tentang kecemasan menghadapi ujian, dapat disimpulkan bahwa siswa yang memiliki tingkat kecemasan menghadapi ujian kategori sangat tinggi dengan ketentuan skor $>107$ berjumlah 4 orang, kategori tinggi dengan ketentuan skor antara 97-106 berjumlah 3 orang, kategori sedang dengan skor antara 86-96 berjumlah 2 orang. 8 orang siswa memiliki kecemasan menghadapi ujian Tabel 2. Post-test

\begin{tabular}{ccc}
\hline Interval & Frekuensi & Kategori \\
\hline$>107$ & - & Sangat Tinggi \\
\hline $97-106$ & - & Tinggi \\
\hline $86-96$ & 1 & Sedang \\
\hline $65-85$ & 5 & Rendah \\
\hline$<64$ & 4 & Sangat Rendah \\
\hline Total & $\mathbf{1 0}$ & \\
\hline
\end{tabular}

Berdasarkan hasil pos-test setelah dilakukannya perlakuan (treatment) layanan konseling kelompok dengan teknik restrukturisasi kognititf yang menggambarkan adanya penurunan rendah dengan skor 65-85 dan 1 orang siswa yang memiliki kecemasan menghadapi ujian sangat rendah dengan skor <64. Sampel yang termasuk dalam kategori sangat tinggi 4 orang siswa, kategori tinggi 4 orang siswa dan kategori sedang 2 orang siswa yang mengalami kecemasan menghadapi ujian dan berjumlah 10 orang siswa diberi treatment berupa konseling kelompok dengan teknik restrukturisasi kognitif. 
sedang dengan persentasenya sebesar $10 \%$ dengan interval (86-96). 5 orang siswa mengalami penurunan menjadi kategori rendah, dengan persentasenya sebesar $50 \%$ dengan interval (65-85) dan 4 orang siswa mengalamai penurunan menjadi kategori sangat rendah dengan persentasenya sebesar $40 \%$ dengan interval $(<64)$.

Tabel 3.

Hasil Penurunan Skor Pre-test dan Post test

\begin{tabular}{ccccccc}
\hline No & Responden & \multicolumn{2}{c}{ Pre-test } & \multicolumn{2}{l}{ Post-test } & Penurunan \\
\hline & & Skor & Kategori & Skor & Kategori & \\
\hline 1. & AA & 91 & Sedang & 84 & Rendah & 7 \\
\hline 2. & ATWA & 105 & Tinggi & 79 & Rendah & 26 \\
\hline 3. & APH & 91 & Sedang & 58 & Sangat rendah & 33 \\
\hline 4. & LS & 122 & Sangat tinggi & 73 & Rendah & 49 \\
\hline 5. & JN & 100 & Tinggi & 74 & Rendah & 26 \\
\hline 6. & MRAA & 128 & Sangat tinggi & 85 & Rendah & 43 \\
\hline 7. & STW & 118 & Sangat tinggi & 67 & Sangat rendah & 51 \\
\hline 8. & WF & 126 & Sangat tinggi & 96 & Sedang & 30 \\
\hline 9. & JMK & 103 & Tinggi & 63 & Sangat rendah & 40 \\
\hline 10. & SS & 106 & Tinggi & 64 & Sangat rendah & 42 \\
\hline & Jumlah & $\mathbf{1 0 9 0}$ & & $\mathbf{7 4 3}$ & $\mathbf{3 4 7}$ \\
\hline & Mean & $\mathbf{1 0 9 , 0}$ & & $\mathbf{7 4 , 3}$ & \\
\hline
\end{tabular}

Berdasarkan pada tabel 3. dapat dilihat bahwa adanya perbedaan antara mean pretest 109,0 dan mean post-test 74,3 yang artinya setelah dilakukan perlakuan (treatment), terjadi penurunan dengan mean kecemasan menghadapi ujian sebesar 34,7 maka dapat disimpulkan bahwa adanya penurunan kecemasan siswa menghadapi ujian dan terdapat efektivitas layanan konseling kelompok dengan teknik restrukturisasi kognitif untuk mereduksi kecemasan menghadapi ujian siswa kelas VII di SMP N 22 Kota Bengkulu. 
Uji Hipotesis

Hipotesis dalam penelitian ini adalah untuk menguji apakah terdapat efektivitas layanan konseling kelompok dengan teknik restrukturisasi kognitif untuk mereduksi kecemasan menghadapi ujian siswa kelas VII C di SMP Negeri 22 Kota Bengkulu, maka untuk menguji hipotesis tersebut peneliti menggunakan uji $\mathrm{Z}$ dengan menggunakan software statistical packages for social scince SPSS versi 16.0 dengan uji Wilcoxon Signed Ranks Test. Hasil uji hipotesis dapat dilihat pada tabel berikut ini :

Tabel 4.

Wilcoxon Signed Rank Test (Uji Z)

\begin{tabular}{lll}
\hline No. & & Pretest-Posttest \\
\hline 1. & $\mathrm{Z}$ & $-2.805^{\mathrm{a}}$ \\
\hline 2. & Sig. (2-tailed) & 0.005 \\
\hline
\end{tabular}

Berdasarkan taraf signifikansi (2tailed) adalah 0.005. Itu berarti nilai signifikansi (2-tailed) $0.005<0.05$. Kriteria penerimaan atau penolakan hipotesis itu berarti Ho ditolak dan $\mathrm{Ha}$ diterima. Oleh karena itu dapat disimpulkan bahwa ada perbedaan yang signifikan kecemasan menghadapi ujian siswa sebelum dan sesudah diberikan layanan konseling kelompok dengan teknik restrukturisasi kognitif pada siswa kelas VII C SMP N 22 Kota Bengkulu.

\section{Kesimpulan}

Berdasarkan hasil penelitian yang telah dilakukan, dapat disimpulkan bahwa tingginya kecemasan menghadapi ujian siswa sebelum diberikan layanan konseling kelompok dengan teknik restrukturisasi kognitif dari 19 siswa di kelas VII C

didapat 10 orang siswa rata-rata berada dalam kategori tinggi. Setelah diberikan layanan konseling kelompok dengan teknik restrukturisasi kognitif dari 10 orang siswa yang mengalami kecemasan menghadapi ujian dengan kategori tinggi, menjadi 1 orang siswa menurun menjadi sedang, 5 orang siswa menurun menjadi rendah dan 4 orang siswa sangat rendah.

Alasan penulis menggunakan teknik restrukturisasi kognitif, sebagai strategi pemecahan masalah yang dialami oleh anak. Bahwa seharusnya mengajarkan anak untuk tidak berpikir "apa" melainkan "bagaimana" dalam melakukan sesuatu, serta untuk memfasilitasi dalam memecahkan permasalahan anak. Pelatihan restrukturisasi kognitif adalah suatu teknik untuk membantu klien berpikir dengan rasional bagaimana mengubah pikiran yang tidak rasional dan 
langsung mengatasi permasalahan yang ada didalam diri siswa. Kegiatan konseling kelompok menggunakan teknik restrukturisasi kognitif dirasakan tepat untuk mengurangi kecemasan siswa menghadapi ujian. Dapat disimpulkan bahwa pemberian konseling kelompok teknik restrukturisasi kognitif sesuai dengan prosedur dan cukup efektif untuk menurunkan kecemasan siswa menghadapi ujian.

Artinya ada efektivitas dari treatment (perlakuan) menggunakan layanan konseling kelompok dengan teknik restrukturisasi kognitif untuk menurunkan kecemasan siswa menghadapi ujian. Hal ini dapat dibuktikan dari hasil analisis data yang menyebutkan bahwa Ho ditolak dan Ha diterima yang berarti terdapat efektivitas layanan konseling kelompok teknik restrukturisasi kognitif untuk mereduksi kecemasan siswa menghadapi ujian.

\section{Daftar Pustaka}

Apriyanti, S. (2013). Efektivitas Teknik Restrukturisasi Kognitif untuk Mereduksi Kecemasan Komunikasi Pada Remaja terhadap Peserta Didik Kelas X SMA Pasundan 2 Bandung. Skripsi. Universitas Putra Indonesia.

Eriord, Bradley T.(2016). 40 Teknik yang Harus Diketahui Setiap Konselor. Yogyakarta: Pustaka Pelajar.
Kartini Kartono. (2002). Kamus Lengkap Psikologi. Jakarta: Raja Grafindo Persada.

Krisnayana T.A. I N, Dkk. (2014). Penerapan Konseling Kognitif dengan Teknik Restrukturisasi Kognitif untuk Meningkatkan Resiliensi Siswa Kelas XI IPA 1 SMA NEGERI 3 SINGARAJA. Jurnal Bimbingan dan Konseling. Universitas Pendidikan Ganesha. Singaraja. Vol 2 No 1. Diakses tanggal 27 Januari 2017.

Mahudi, Farid. (2012). Psikologi Konseling. Yogyakarta: IRCiSoD

Martono, Nanang. (2014). Metode Penelitian Kuantitatif Analisis Isi dan Analisis Data Sekunder. Jakarta: Raja Grafindo Persada.

Nurihsan, A.J. (2011). Bimbingan dan Konseling dalam Berbagai Latar Kehidupan. Bandung: Refika Aditama.

Prasetyono, D.S. (2005). Kiat Mengatasi Cemas dan Depresi. Yogyakarta: Tugu Publisher.

Prayitno. (2012). Layanan Bimbingan Dan Konseling Kelompok Dasar Dan Profil. Jakarta: Rineka Cipta.

Slameto. (2010). Belajar dan FaktorFaktor yang Mempengaruhinya. Jakarta: Erlangga. 